\title{
Ditadura militar sob o olhar de composições musicais
}

Military Dictatorship under the eyes of musical compositions

Flávia Jovelino da Silva*

\section{Resumo}

$\mathrm{O}$ artigo apresenta o trabalho desenvolvido como professora da rede pública de ensino do município do Rio de Janeiro e supervisora do Projeto de Iniciação à Docência de licenciatura de História, da Universidade do Estado do Rio de Janeiro (Maracanã). Utilizei letras de canções populares das décadas de 1960 e 1970 com alunos do último ano do ensino fundamental, nas aulas sobre Ditadura Militar no Brasil, destacando a relevância das canções como fonte de pesquisa e reflexão desse período. Além disso, foi possível dialogar entre o tema estudado e a realidade vivenciada por eles, que naquele momento conviviam com o Exército em sua comunidade, com a instalação de uma Unidade de Polícia Pacificadora no Complexo da Maré. O projeto foi finalizado com a produção de composições musicais elaboradas pelos educandos.

Palavras-chave: ensino de História; canção e ditadura militar.

\begin{abstract}
This article shows my work developed as a teacher of the public education network of the city of Rio de Janeiro and supervisor of the Project of Initiation to Teaching of History degree from the Universidade do Estado do Rio de Janeiro (Maracanã). I used lyrics of popular songs of the 1960s and 1970s with seniors of the last year of elementary school in the classes on Military Dictatorship in Brazil, highlighting the relevance of songs as a source of research and reflection of this period. In addition, it was possible to cross the studied subject with the reality experienced by them, who at that time lived with the Army in their community, due to the installation of a special Police Unity in the Maré Complex. The students finalized the work composing songs.

Keywords: History teaching; songs and military dictatorship.
\end{abstract}

\footnotetext{
* Licenciada em História, Faculdade de Formação de Professores (FFP) - Universidade do Estado do Rio de Janeiro (UERJ). Pós-Graduação em História e Cultura no Brasil, Universidade Estácio de Sá. Docente das Redes Estadual e Municipal do Rio de Janeiro. Rio de Janeiro, RJ, Brasil. flaviajdasilva@hotmail.com
} 
Por QUe trabalhar COM MÚSICA POPUlar NA AUla De HistóRIa?

Este artigo tem como escopo apresentar experiências em sala de aula no ensino de História, em escola da rede pública de ensino do Rio de Janeiro situada no bairro de Bonsucesso, e que atende alunos do segundo segmento do ensino fundamental, os quais em sua maioria residem no Complexo da Maré.

O trabalho foi desenvolvido em 2015, quando eu atuava como supervisora do Projeto de Iniciação à Docência em licenciatura de História, orientado pela professora Carina Martins, da Universidade do Estado do Rio de Janeiro (campus Maracanã) e apoiado pela Coordenação de Aperfeiçoamento de Pessoal de Nível Superior (Capes).

Dentre as atividades desenvolvidas em parceria com o Programa Institucional de Bolsas de Iniciação à Docência (Pibid), destacou-se o trabalho aqui relatado, que privilegiou a relação entre ensino de História e composições musicais, tendo em vista a relevância dessa linguagem no diagnóstico dos saberes discentes, organizado pelos bolsistas por meio de um questionário semiestruturado na referida unidade escolar entre os anos de 2014 e 2015.

A “enquete" respondida pelos educandos apresentou a relevância da música popular como mecanismo eficaz de linguagem, podendo ser trabalhado em amplas diretrizes. Sua presença é notória tanto no espaço físico quanto pedagógico da escola, graças a sua própria natureza, que possibilita tal flexibilidade. Dessa forma, atuamos em conformidade com a Lei federal $n^{\circ}$ 11.769/08, a qual salienta a importância do ensino de música nas unidades básicas de ensino.

O trabalho com letras de canções populares foi desenvolvido em diálogo com o tema Ditadura Militar no Brasil. A escolha desse tópico e das fontes surgiu das dificuldades apresentadas por alguns alunos do último ano do ensino fundamental em 2014, que ao realizarem avaliação externa de História, elaborada pela Secretaria Municipal de Educação do Rio de Janeiro, não conseguiram relacionar a letra da música Roda Viva, de Chico Buarque (1968), ao contexto de censura estabelecido durante a Ditadura.

Além disso, a seleção do tema não ocorreu por mero cumprimento do conteúdo programático para o ensino de História do $9^{\circ}$ ano, mas, por alguns elementos que permeavam a realidade de nosso alunado. Dentre os motivos, podemos destacar: as notícias e manchetes que circulavam nos meios de comunicação apontando o retorno da ditadura militar no cenário brasileiro, 
circunstância que fez alguns estudantes questionarem, em sala de aula, o que "deveriam pensar a respeito de tal assunto". Ao mesmo tempo, o Complexo da Maré, comunidade onde os alunos moravam, convivia com o Exército, que dava prosseguimento ao projeto de instalação de Unidades de Polícia Pacificadora (UPPs), política pública adotada pelo governo do Rio de Janeiro desde 2008.

A partir desses eventos buscou-se desenvolver um projeto em sala de aula que trabalhasse com documentos como letras de músicas, imagens, propagandas e normas jurídicas, entre outros exemplos, para abordar não apenas o mencionado tópico, mas também diferentes assuntos presentes no currículo escolar. Nesse contexto foi necessário trabalho de pesquisa, uma vez que o livro didático não contemplava essa finalidade. Este não foi rejeitado, pois serviu em alguns momentos como mecanismo de apoio para atividades e ou representações iconográficas.

No âmbito deste projeto usamos a ideia de música popular, "canção", como produto do século XX, ligado às camadas populares e médias e intimamente relacionado à busca por excitação corporal e emocional (Hermeto, 2012, p.31).

Por suas características peculiares a linguagem cancional tem sido importante instrumento no processo de ensino/aprendizagem, uma vez que está presente no cotidiano dos estudantes, contribuindo para a construção de capacidades de leitura de mundo (Hermeto, 2012, p.15), expondo elementos como ideologias, críticas e outros aspectos de uma sociedade a ser trabalhada.

Assim como outras linguagens aplicáveis em sala de aula, a canção popular brasileira como fonte de pesquisa visa desenvolver entre os educandos a compreensão do processo histórico, e permite conscientizá-lo de que é um agente na sociedade. Igualmente, possibilita despertar senso crítico, pois assim como demais produções artísticas, a composição musical não constitui discurso "neutro", ao contrário, apresenta determinada realidade social pensada e arquitetada, constrói e veicula representações sociais, exercendo papel ativo na construção de significados para o mundo (Hermeto, 2012, p.15).

Além disso, essa fonte de pesquisa nos possibilita dialogar com outras disciplinas e abordar assuntos antes esquecidos ou parcamente desenvolvidos no ensino de História, como gênero, moda e culinária, entre outros temas.

Adotando tal conduta demonstramos aos educandos que o estudo da História "os ajuda a entender o mundo no qual vivem de maneira que os farão se desenvolver como seres humanos autônomos” (Lee, 2012, p.219). 
Desenvolvemos nosso trabalho pensando no que Peter Lee denominou de "empatia", que busca compreender o entendimento histórico que os alunos possuem, ou seja, como eles constroem a base do conhecimento histórico, e se eles tratam a história simplesmente como informação dada.

Nesse contexto, é importante atuarmos no sentido de buscar elementos que estabeleçam relação entre o conhecimento trazido pelo aluno e a informação científica ensinada na escola, pois é complexo para o educando aprender algo que para ele não apresenta sentido ou relevância. Conforme declarou Peter Lee, a educação histórica deve envolver os alunos em:

Aprender um conhecimento histórico concreto: um engajamento com o conteúdo histórico; Entender características centrais de evidência, explicação e relatos históricos (tomadas para incluir noções de significância, mudança e outros conceitos-chave); Adquirir as disposições (paixões racionais) que apoiam o questionamento histórico do passado. (Lee, 2012, p.230)

Esse autor também afirmou que a história não deve ser pensada ou orientada para criar "certos tipos de padrão": democratas exemplares, cidadãos nacionalistas ou algo semelhante. A tarefa do ensino de história é criar:

Uma forma de olhar o passado que não permita a ninguém possuí-lo, e mais ainda exija que aceitemos histórias que vão contra os nossos interesses práticos e até mesmo os nossos sentimentos mais profundos - sejam estes relacionados à identidade, feridas e encargos ... permite leituras do passado que abrem caminhos diferentes daqueles exigidos pelos nossos interesses práticos. Pode mesmo mudar o sentido de quem somos, o que podemos e não podemos fazer, e até mesmo nossas crenças sobre o que pode ser estabelecido como fato. (Lee, 2012, p.226)

Dessa forma, dentre os elementos relevantes na tarefa do professor podemos destacar o estímulo ao desenvolvimento da aprendizagem, e para isso é necessário saber de quais valores os educandos se apropriaram, despertando neles a compreensão de seu papel de agente social, capaz de questionar e construir um conhecimento histórico, não sendo um "mero espectador e receptor de informações". 


\section{Diálogo entre ditadura militar e Canções de Chico Buarque}

As canções de Chico Buarque foram utilizadas, inicialmente, como mecanismos de "problematização", introdução ao tema. Trabalhou-se com letras de música como: Apesar de Você, Cálice e Roda Viva, todas de Chico Buarque (a segunda em parceria com Gilberto Gil), além de outras mencionadas no decorrer das aulas.

Nesse processo de ensino/aprendizagem os documentos se transformaram em recursos didáticos, quando evocados para responder perguntas e questionamentos adequados aos objetivos da história pesquisada. Iniciamos nosso trabalho buscando nas letras elementos que pudessem levar o aluno a questionar e compreender circunstâncias que permeavam a censura, especialmente no âmbito dos meios de comunicação e de diversão pública no Brasil, no período entre 1968 e 1974.

Quadro 1 - Desenvolvimento das etapas do projeto

\begin{tabular}{|c|c|c|c|}
\hline I Etapa & II Etapa & III Etapa & IV Etapa \\
\hline Problematização & $\begin{array}{c}\text { Aulas } \\
\text { expositivas }\end{array}$ & $\begin{array}{c}\text { Compreensão de } \\
\text { conhecimentos }\end{array}$ & Avaliação \\
\hline $\begin{array}{l}\text { 10 Momento: } \\
\text { Direcionamento da } \\
\text { Leitura das } \\
\text { composições } \\
\text { selecionadas - } \\
\text { Roda Viva, Apesar } \\
\text { de Você e Cálice. }\end{array}$ & $\begin{array}{l}4^{\circ} \text { Momento: } \\
\text { A Ditadura } \\
\text { Militar no } \\
\text { Brasil - seu } \\
\text { advento e } \\
\text { fases. }\end{array}$ & \multirow{3}{*}{$\begin{array}{l}\text { 60 }^{\mathbf{0}} \text { Momento: } \\
\text { Releitura das } \\
\text { composições } \\
\text { musicais, } \\
\text { abordando-as } \\
\text { como } \\
\text { documentos de } \\
\text { crítica ao } \\
\text { Governo Militar. }\end{array}$} & \multirow[t]{3}{*}{$\begin{array}{l}7^{\circ} \text { Momento: } \\
\text { Elaboração de } \\
\text { composições musicais, } \\
\text { pensando a canção } \\
\text { como elemento de } \\
\text { expressão de uma } \\
\text { realidade histórica. }\end{array}$} \\
\hline $\begin{array}{l}2^{\circ} \text { Momento: } \\
\text { Apresentação das } \\
\text { canções - texto e } \\
\text { melodia. }\end{array}$ & \multirow{2}{*}{$\begin{array}{l}5^{\circ} \text { Momento: } \\
\text { Ênfase no } \\
\text { Governo } \\
\text { Médici: "anos } \\
\text { de chumbo". }\end{array}$} & & \\
\hline $\begin{array}{l}3^{\circ} \text { Momento: } \\
\text { Informações sobre } \\
\text { o interprete das } \\
\text { canções. }\end{array}$ & & & \\
\hline
\end{tabular}




\section{Etapa}

10 Momento: leitura das composições selecionadas - Roda Viva (1968), Apesar de Você (1970) e Cálice (1973).

Os educandos separados em grupos (duplas ou trios) foram orientados a fazer uma primeira leitura, com o propósito de sinalizar elementos que entendiam como relevantes e semelhantes entre as letras das canções, a partir de alguns questionamentos:

a) Qual o tema das composições?

b) Os assuntos das três composições se relacionam e/ou apresentam semelhanças?

c) Em sua opinião, qual deve ser o gênero musical das composições apresentadas?

- Nesta etapa, declararam que as três composições apresentavam temas relacionados às ideias de "sofrimento", "decepção" e "saudades".

- Em relação ao gênero musical, ofereceram suas considerações apenas em relação a Cálice, que classificaram como "música religiosa”.

20 Momento: letra e melodia, apresentação das três canções de Chico Buarque para as turmas.

30 Momento: leitura de trecho historiográfico sobre a trajetória artística do intérprete Chico Buarque, além de explicar que a canção é uma forma de tratar a realidade: reconhecê-la, falar dela, dialogar com ela e reconstruí-la, atribuindo-lhe sentido (Hermeto, 2012, p.35).

\section{Etapa}

$4^{\circ}$ Momento: as aulas expositivas sobre o tema foram direcionadas tanto pelo uso de pequenos textos historiográficos, quanto pelo diálogo com outras fontes históricas como documentos iconográficos, reportagens, decretos e testemunhos, entre outros elementos capazes de organizar o conhecimento histórico.

Em um primeiro momento, o tema foi direcionado para a compreensão do contexto social e político do período que antecedeu ao golpe, as ingerências internas e externas, que "derrubaram” em 1964 o governo de João Goulart. 
Concomitantemente ao estudo desse tópico, foram sendo trabalhados, confirmados ou relembrados conceitos como capitalismo, comunismo, subversão, ditadura, golpe e democracia.

Além disso, debateram-se as normas legais (atos, leis, decretos etc.) que validaram o banimento de grupos de esquerda como sindicatos e movimentos estudantis das decisões políticas do país, e que ao mesmo tempo sancionavam os governos antidemocratas e autoritários.

\section{Objetivos:}

$\triangleright$ Entender que a Ditadura de 1964 resultou de uma conjunção complexa de condições, de processos e de ações, cuja compreensão permite elucidar o que deixou surpresos e perplexos os contemporâneos, vencidos e vencedores (Reis, 2014, p.18).

$\triangleright$ Perceber o cenário, em relação à repressão e censura nas três fases da Ditadura Militar, conforme apresenta José Murilo de Carvalho (2004, p.157):

- $1^{\text {a }}$ Fase (1964-1968): Governo dos generais Castelo Branco e Costa e Silva, com intensa atividade repressiva, mas seguidos de sinais de abrandamento.

- 2a Fase (1969-1974): Governo do general Garrastazu Médici, período de grande repressão política no país.

- $3^{\text {a }}$ Fase (1974-1985): Governo dos generais Ernesto Geisel (19741979) e João Batista de Figueiredo (1979-1985), momento de progressiva abertura política no país.

$5^{\circ}$ Momento: autoritarismo e censura durante os "anos de chumbo".

Salientar que o governo na vigência do general Garrastazu Médici, mesmo tendo ratificado o autoritarismo do regime nas mãos dos militares, teve apoio de expressiva parcela da sociedade civil brasileira, seja por inocência, por não ter conhecimento dos excessos de violência cometidos contra os "subversivos", seja por neutralidade, ou mesmo por ter se beneficiado de alguma das reformas traçadas pelo Estado como o Fundo de Assistência ao Trabalhador Rural (Funrural), que estabelecia o salário mínimo e aposentadoria para mulheres e homens do campo (Reis, 2014, p.85). 
Compreender que no começo dos anos 1970 uma expressiva parcela das composições musicais, especialmente a sertaneja, muito mais consumida que a chamada Música Popular Brasileira (MPB), apresentava em suas letras a confirmação da popularidade e da admiração ao ditador-presidente (Reis, 2014, p.82).

Mesmo com os esforços dos militares e com as atitudes autoritárias, as normas legais como o Ato Institucional número 5 (AI-5), estabelecido em dezembro de 1968, fizeram que se disseminasse em sociedades de opiniões públicas mais atentas a ideia de que existia uma ditadura violenta no Brasil, e o aparecimento de denúncias, cada vez mais numerosas e consistentes, do emprego da tortura como política de Estado (Reis, 2014, p.84).

Igualmente, os alunos compreenderam o grau de censura e cerceamento de liberdade imposto ao povo brasileiro naquele período, situação que levou muitas pessoas a perderem familiares, empregos e até mesmo o direito de viver no país.

Seguindo o curso do tema abordaram-se as formas de restrições de liberdade durante a Ditadura, quando muitos tiveram os seus direitos políticos cassados, outros foram investigados, presos arbitrariamente, torturados ou até mortos.

Nesse âmbito, destacou-se um breve relato de Manoel Dias do Nascimento, presente na obra Infância Roubada. No depoimento, o militante preso em 1970 expõe algumas das torturas físicas e psicológicas que ele e sua família tiveram de enfrentar. Manoel Dias só conseguiu ser solto quando ele e outros presos políticos foram trocados pelo embaixador suíço Giovanni Enrico Bücher, sequestrado por aqueles que resistiam à Ditadura (Nascimento, 2014, p.144).

Antes de eu descer do pau de arara, minha companheira chegou com meu filho. Este filho assistiu a parte da tortura. Em seguida, puseram minha companheira no pau de arara, tomando choque em todas as partes do corpo, inclusive nas partes íntimas. Na minha presença. Só para eu falar alguma coisa, relatou Manoel. Chorando muito, Jovelina testemunhou: Ele [o filho Ernesto] dizia: Não pode bater no papai. Não pode. Para mim foi muito duro. Batiam muito em mim.

Destacar os meios de comunicação como o rádio e a televisão, elementos de entretenimento e lazer para as massas, que serviam como veículos de 
publicidade utilizados pelo Governo Médici, a fim de propagar pelo país os slogans "Brasil, ame-o ou deixe-o" e "Ninguém segura este país", entre outros.

Em contrapartida aos elementos que mantiveram os militares no poder por um considerável período, abordaram-se os inúmeros movimentos de resistência favoráveis à abertura política no final da década de 1970, que clamavam pelo retorno à democracia, o fim da censura, a anistia e o retorno dos exilados, entre outros "pedidos de liberdade".

\section{Etapa}

$6^{\circ}$ Momento: releitura e análise das canções selecionadas, contextualizando com o período de "chumbo" da Ditadura Militar.

Os alunos foram orientados a repassar as palavras/ideias que haviam destacado nas letras das composições durante a etapa da problematização; ao mesmo tempo, foram instigados a relacioná-las ao tema em questão, circunstância que os fez compreender tais músicas como mecanismo de crítica e resistência naquele momento do Brasil.

Com essas elucidações - nas quais se ressaltaram as práticas autoritárias do Governo e a ação das organizações contrárias à Ditadura Militar - houve a releitura das composições, identificando o que não havia sido compreendido, ou simplesmente não fora sinalizado na primeira leitura, destacando, neste segundo momento, quais eram as intenções do compositor e que artifícios foram utilizados para ludibriar a censura.

Igualmente, demonstrou-se a relevância da canção popular brasileira como ferramenta e fonte de pesquisa para a construção do conhecimento histórico, elemento que nos possibilitou o diálogo entre as composições e o tema Ditadura.

\section{Etapa}

$7^{\circ}$ Momento: produção das composições musicais

Após as fases apresentadas, os educandos retornaram às suas equipes originais e, supervisionados, preencheram uma ficha de análise - conforme sugestão apresentada na obra Canção Popular de Miriam Hermeto (2012, p.156) -, com a finalidade de sistematizar o que ponderaram sobre as músicas: autoria, gênero e contextualização das canções ao momento histórico evidenciado. 


\begin{tabular}{|l|}
\hline Título: \\
\hline Autor: \\
\hline Data da Produção: \\
\hline Local da Produção: \\
\hline Gênero Musical: \\
\hline Relação da música com o tema: \\
\hline Observações e curiosidades sobre a composição musical: \\
\hline Opinião do grupo sobre a abordagem do fato histórico na música: \\
\hline
\end{tabular}

Após trabalhar com a questão da censura na Ditadura Militar e fazer a releitura das letras das canções, os alunos compreenderam a narrativa do autor ao expor com metáforas a sua visão da realidade, demonstrando repúdio, melancolia e tristeza diante do autoritarismo imposto à sociedade brasileira daquele período.

O desfecho do projeto ocorreu mediante a preparação de canções (letra e melodia) elaboradas pelos alunos. As equipes direcionaram seus trabalhos a partir de duas propostas: discorrer sobre as atrocidades e censuras empreendidas durante os "anos de Chumbo" da Ditadura Militar e refletir sobre situações "polêmicas" da sociedade/comunidade da qual participavam, utilizando para isso metáforas e/ou outras figuras de linguagem, como nas composições de protesto de Chico Buarque.

Essa atividade teve como finalidade verificar se os alunos compreenderam os assuntos abordados durante as aulas e como refletiram sobre eles, além de demonstrar que a canção popular pode ser importante mecanismo de diálogo e representação de um fato histórico.

As equipes foram orientadas a desenvolver suas letras em acordo com as regras de língua portuguesa, utilizando versos e estrofes, mas respeitou-se o uso de palavras e expressões próprias de suas localidades e a escolha do estilo musical de sua preferência - neste caso evidenciou-se o uso de funk, rap e pagode, conforme podemos verificar nas letras selecionadas a seguir: 
TítUlo: A vida

AUTOR: Grupo I

DATA DA PRODUÇÃO: 2015

ESCOLA/TURMA: E. M. Bahia/8901

GÊNERo Musical: Pagode

RELAÇÃO DA MÚSICA COM O TEMA: crítica à violência (no contexto da realidade de sua comunidade) e utilização da metáfora, figura de linguagem muito utilizada na elaboração das músicas no contexto da Ditadura Militar. OBSERVAÇÕES E CURIOSIDADES SOBRE A COMPOSIÇÃO MUSICAL: questionamento à violência na comunidade onde residiam.

\section{A Vida}

Dessa vez é melhor parar

Ou vai chorar

Recebi uma notícia da comunidade

Já tá tudo na cara, meu irmão.

Não dá mais para ficar assim

Você não sabe como isso é ruim pra mim

Deixa para lá

Não dá mais para ficar assim

Você não sabe como isso é ruim pra mim.

Se não existe mais paz no ambiente

Encontrar um outro caminho na vida, é urgente

Vou sair daqui...

Quero ir para um lugar diferente! 
TÍTULO: Tanta promessa jogada fora

AUTOR: Grupo II

DATA DA PRODUÇÃO: 2015

ESCOLA/TURMA: E. M. Bahia/8801

GÊNERO MUSICAL: Rap

RELAÇÃO DA MÚSICA COM O TEMA: trabalhou com situações e fatos ocorridos durante a Ditadura Militar como as torturas, censuras e, em especial, com o caso de Ernesto Carlos Dias do Nascimento (1970).

OBSERVAÇÕES E CURIOSIDADES SOBRE A COMPOSIÇÃO MUSICAL: trabalhou com fatos ocorridos durante a Ditadura Militar e situações vivenciadas nos dias de hoje, mas que muitas vezes não são noticiadas pelos meios de comunicação.

\section{Tanta promessa jogada fora}

Dizem que o Brasil está na paz? A violência toma conta de tudo Até mesmo dos jornais

\section{Tudo tem suas leis}

Se não tiver é censurado Igual àquele que algum tempo foi torturado!

Sua pena? Morrer afogado!

As leis no mundo são severas Aqui, no Brasil, já vimos cadeira elétrica.
Inveja, ódio, destruição...

Malandragem e corrupção.

De maneira semelhante, Coitada daquela criança Que viu seu pai sofrer adiante Gritos e coisas semelhantes Foram ouvidos naquele instante.

Onde está a paz?

Essa pergunta é difícil de fazer As coisas são secundárias E nunca vão para a TV. 
Título: A Realidade

AUTOR: Grupo III

DATA DA PRODUÇÃO: 2015

GÊNERO MUSICAL: Funk

ESCOLA/TURMA: E. M. Bahia/ 8801

RELAÇÃO DA MÚSICA COM O TEMA ESTUDADO: crítica à violência e a condição da pacificação pelas Forças Armadas dentro da comunidade da Maré.

OBSERVAÇÕES E CURIOSIDADES SOBRE A COMPOSIÇÃO MUSICAL: Utilização de termos e expressões comuns dentro da comunidade, que estão presentes no cotidiano dos moradores, seja através de conversas ou de inscrições em muros e paredes como as palavras: "facção", "boladão" e "periquitos", ou da frase "Jesus é o dono do lugar".

\section{A Realidade}

Na nossa comunidade tem facção

Nossa segurança é Deus

Quem sabe, sabe. Sabe da realidade

Que muitos não colocam na televisão.

Os periquitos ficam boladão

Só pensam em judiação

São sem noção, são sem noção

Não precisa de divisão.

Nós queremos paz, amor e consideração...

Jesus é o dono do lugar

O melhor está por vir

Sem previsão, sem previsão de uma nova nação.

(Repetir a música) 
TÍTULO: Escuridão

AUTOR: Grupo IV

DATA DA PRODUÇÃO: 2015

ESCOLA/TURMA: E. M. Bahia/8901

GÊNERO MUSICAL: Rap

RELAÇÃO DA MÚSICA COM O TEMA ESTUDADO: trabalhou com metáforas, mencionou as prisões arbitrárias, os protestos e reivindicações da sociedade naquele período histórico e na atualidade.

OBSERVAÇÕES E CURIOSIDADES SOBRE A COMPOSIÇÃO MUSICAL: relacionar a música de Chico Buarque ao contexto de protesto, durante a Ditadura Militar. E na última estrofe expõe elementos que ainda são motivo de protesto em nossa sociedade.

\section{Escuridão}

Chico Buarque cantava uma música

Que falava de escuridão

Para aqueles que estavam na prisão

Presos por subversão.

E mortos sem compaixão.

As famílias ficavam preocupadas,

Não achavam pista de nada

Os que iam para rua choravam, lutavam e cantavam

Atrás de seus amados que por liberdade lutaram.

Os Hospitais sem aparelhos

$E$ as crianças no desespero

As pessoas protestavam

Os políticos só roubavam

Os gringos apenas observavam. 


\section{CONSIDERAÇÕES FINAIS}

No decorrer das atividades deste projeto, iniciadas com a leitura e análise de canções populares de Chico Buarque, foi possível verificar o alcance e o encanto que essa ferramenta, empregada como objeto e fonte de estudo, exerceu sobre os educandos, circunstância que lhes possibilitou interagirem melhor com o tema proposto.

Os alunos compreenderam que diversas composições musicais daquele período estavam repletas de opiniões e valores, assim como produções artísticas do "nosso tempo", que apresentam mensagens muitas vezes ligadas a grupos, comunidades e eventos específicos.

Igualmente, ao criarem suas próprias canções, os alunos desenvolveram habilidades como criatividade, síntese e compreensão de figuras de linguagem, além de um olhar crítico, tanto sobre fatos históricos daquele período, quanto sobre sua própria realidade. Enfim, por meio de um elemento de aprendizagem não habitual em sala de aula - a canção - foi possível desenvolver com os educandos um trabalho eficaz e aprazível.

Na letra das músicas criadas pelos educandos identificou-se que eles compreenderam elementos importantes sobre o tema, de tal maneira que apresentaram em suas "produções musicais" informações como prisões arbitrárias, castigos impostos a prisioneiros políticos e falta de liberdade de expressão, entre outras circunstâncias pertinentes àquele período "sombrio" da História do Brasil.

As composições musicais dos educandos também nos proporcionaram apreciar melhor seu olhar em relação ao momento vivenciado no Complexo da Maré e conhecermos termos e expressões singulares cunhadas no âmbito da comunidade - como "periquitos", referência aos soldados do Exército, que passaram a fazer barricadas e a circular com armas, caminhões e tanques pelas ruas, ou a frase "Jesus é o dono do lugar", que a princípio parece uma expressão religiosa, mas que para os alunos era elemento comum, presente em diversas pichações de paredes e muros da comunidade e aceita até mesmo por aqueles vinculados à criminalidade local.

Igualmente, devemos destacar a capacidade dos alunos ao apresentar críticas em seus textos, não só em relação ao autoritarismo presente na Ditadura Militar, como também em relação à sociedade, e o inconformismo com a 
corrupção, desigualdade, controle dos meios de comunicação e a violência, entre outros itens que não afligem tão somente a sua comunidade, mas as massas populares de forma geral no país.

O uso da música como documento e fonte de pesquisa apresentou grande eficácia nas aulas de História, não somente no recorte apresentado, mas também em outros temas abordados no decorrer do ano letivo. Ao mesmo tempo, os alunos perceberam a relevância de ter um "olhar crítico" sobre a canção, uma vez que as composições não são construídas a partir da imparcialidade do autor, ao contrário, transmitem mensagens e valores, fruto do contexto social no qual ele está inserido. Do mesmo modo, observou-se que os educandos ampliaram sua noção de fonte histórica, aprimorando estratégias de leitura e aprendizagem.

Com essa experiência constatei um relevante desenvolvimento como educadora, pois ao mesmo tempo em que os alunos interagiam, questionavam e apresentavam suas opiniões sobre a temática estudada, fui instigada a organizar aulas mais dinâmicas, deixando em segundo plano o quadro e o livro didático e me propondo a utilizar outras ferramentas de ensino/aprendizagem.

Pude, também, identificar maior comprometimento por parte de muitos alunos, os quais passaram a se expressar, a escrever e interpretar melhor as atividades propostas em sala de aula.

\section{REFERÊNCIAS}

CARVALHO, José M. de. Cidadania no Brasil: o longo caminho. 6.ed. Rio de Janeiro: Civilização Brasileira, 2004.

LEE, Peter J. O Ensino de História: algumas reflexões do Reino Unido. Entrevista concedida a Cristiani Bereta da Silva. Tempo e Argumento, Florianópolis: Programa de Pós-Graduação em História, Udesc, v.3, n.2, p.216-250, jul./dez. 2012. Disponível em: http://revistas.udesc.br/index.php/tempo/article/view/21751803040 22012216/2166; Acesso em: 20 mar. 2015.

HERMETO, Miriam. Canção Popular Brasileira e Ensino de História: palavras, sons e tantos sentidos. Belo Horizonte: Autêntica, 2012.

LEE, Peter. "Nós fabricamos carros e eles tinham que andar a pé": compreensão das pessoas do passado. In: BARCA, Isabel (Org.) Educação histórica e museus. Braga: Centro de Investigação em Educação; Instituto de Educação e Psicologia; Universidade do Minho, 2003. p.19-36. 
NASCIMENTO, Ernesto Carlos D. do. Los niños nacen para ser felices. In: INFÂNCIA ROUBADA: crianças atingidas pela Ditadura Militar no Brasil. São Paulo: Assembleia Legislativa do Estado de São Paulo; Comissão da Verdade do Estado de São Paulo, 2014. p.138-151.

REIS, Daniel A. Ditadura e democracia no Brasil: do golpe de 1964 à Constituição de 1988. Rio de Janeiro: Zahar, 2014.

Exemplos musicais:

HOLLANDA, Francisco B. de. Apesar de Você. Disponível em: http://www.chicobuarque.com.br/index.html; Acesso em: 20 fev. 2015.

HOLLANDA, Francisco B. de. Roda Viva. Disponível em: http://www.chicobuarque. com.br/index.html/; Acesso em: 20 fev. 2015.

HOLLANDA, Francisco B. de; GIL, Gilberto. Cálice. Disponível em: http://www.chicobuarque.com.br/index.html; Acesso em: 20 fev. 2015.

Artigo recebido em 25 de agosto de 2016. Aprovado em 1º de dezembro de 2016. 